\title{
Landscape Design of Vine Garden of Xishuangbanna Tropical Botanical Garden of Chinese Academy of Sciences
}

\author{
Min Liu \\ The College of Arts and Sciences Yunnan Normal \\ University \\ Kunming, China \\ Xishuangbanna Tropical Botanical Garden, Chinese \\ Academy of Sciences \\ Xishuangbanna, China
}

\author{
Xiuying Qin \\ The College of Arts and Sciences Yunnan Normal \\ University \\ Kunming, China \\ Xishuangbanna Tropical Botanical Garden, Chinese \\ Academy of Sciences \\ Xishuangbanna, China
}

\begin{abstract}
This paper, starting from the historical context of Xishuangbanna and the botanical garden and focusing on local human culture, natural and vine resources, analyzes the landscape characteristics of the Xishuangbanna Tropical Botanical Garden (XTBG) vine garden and mainly discusses the plant landscape of three major landscape regions: the entrance landscape area, the integrated service area and the central landscape area, reflecting the theme of specialized garden with local characteristics themed as "scientific botanical garden", "biological biodiversity", "high enrichment of species" and "from city to countryside".
\end{abstract}

Keywords—tropical botanical garden; vine; specialized garden; Xishuangbanna

\section{INTRODUCTION}

Widely but not evenly distributed, vine [1] exists in many regions of the world, including forests, deserts and rainforest areas, and subtropical and tropical regions have the highest diversity of species of vines. About $1 / 3$ of plant families in the world contain vines [2].

China abounds with vine resources, and of more than 50,000 species of higher plants in China, vines account for more than $10 \%$, most of which are distributed in the tropical and subtropical regions of south China, southwest China, central China and east China. In recent decades, domestic researchers begin to pay close attention to the resource condition, physiological ecology characteristics, breeding technology, ecological adaptability, eco-economic function, biological characteristics, etc. of vines, and the research on landscape application is mainly from the perspective of the classification of life forms of vine. South China has most abundant species of vine resources in China, and according to the survey, there are 1154 species of vine, accounting for about $16 \%$ of the flora [3].

\section{CURRENT Situation OF Vine Garden In ChINA}

There are a great variety of specialized botanical gardens of various forms around the world. Scholars abroad have conducted relatively profound research on vine whether in its physiological and ecological habits or the specific form of landscaping. Especially in landscape design, many botanical gardens have set up vine garden, which has become an important landscape form showing the landscaping level. Some botanical gardens use vines to present the wall garden. For example, the Royal Botanic Gardens, Kew displays important and ornamental vines from all over the world [4]. MFO Park uses rebar materials to establish a huge cube framework for vines to climb, forming a large area of vertical greening landscape including green wall, green columns, etc. In addition, in the entrance of Fairchild Tropical Botanical Garden, different gallery frames matching with vines of different flowering phases, colors, leaves, forms and latitudes are designed as the main plant landscape [5].

In China, few botanical gardens set up vine gardens, mainly including Xiamen Botanical Garden, Shanghai Chenshan Botanical Garden, Guangdong South China Botanical Garden, etc. In Xiamen Botanical Garden, the vine area and the bright-colored shrub area jointly constitute the Lianas Bright-Colored Shrub Area which preserves more than 100 vines, mainly including vines with ornamental leaf, stem and fruit. The plants are displayed according to the family and genus. For the landscape layout, various frames are applied, mostly some pergola form frames. The plant form reflects the species matching with the site, which is the local feature. In Shanghai Chenshan Botanical Garden, the vine garden mainly collects vines from east China and foreign excellent vines of nearly 160 species. The landscape there based on the steel art gallery frame of "Chinese wisteria tunnel" at the entrance and rectangular modern gallery frame creates an overall style of harmony and unity [6]. Apart from the vine species shown in botanical gardens, there are also some vine-themed parks, such as Shanghai Manqu Park, Jiading Wisteria Garden, Guangxi Nanning Qingxiu Hill Park Vine Garden that are based on vine landscaping. 


\section{The Tropical Botanical Garden Vine Garden FIELD CONTEXT}

XTBG vine garden makes full use of abundant plant resources and rich local cultural resources. Located in the northern area of XTBG, the vine garden covers an area of 72 $\mathrm{mu}$. The land parcel here is of strip form, with low-lying south part and high-lying north part, the maximum altitude difference of $6 \mathrm{~m}$, and from west to east, the terrain is also gradually descending, with the altitude difference of only $1 \mathrm{~m}$.

The Vine Garden was built on a previous residential complex of XTBG staff, and some original facilities including hundreds of trees, staff canteen, sports field, staff residential buildings, apartment for floating personnel, etc. are retained. In the middle of the Vine Garden is a main road, which runs through the whole garden from east to west, and is near the Fruit Garden to the east, near the Bamboo Garden and the Flower Garden to the west, near the Office Area and the Commemorative Plant Garden to the south, and near the Tropical Rain Forest to the north. According to the master plan of XTBG, the staff residential zone is entirely relocated to the residence community outside XTBG, and after the relocation, the region was planned for the construction of specialized garden mainly for conservation and display of the typical tropical plant--vines. In the stage of engineering construction, the staff canteen was transformed for reuse; the apartment for floating personnel cannot be removed so was retained; some buildings and walls of the staff residence were retained to record the historical signs of the staff living here. The buildings and walls retained are used to support climbing plants, which becomes a unique form of display.

\section{LANDSCAPE CHARACTERISTICS OF XTBG VINE GARDEN}

From the perspective of XTBG traditional context, the designer of the XTBG Vine Garden referred to the landscaping methods Chinese traditional gardens and introduced the connotation of scientific botanical gardens and regional culture to create this unique tropical vine garden according to the needs of vines for habitat. The design of the Vine Garden reflects the theme from gardening display to nature and the style from city to countryside; it makes full use of the space frames of old buildings, walls and fences, and of the natural forests to introduce climbing plants to form vertical greening, suggesting that vines, as the common plant materials used in landscape architecture, are an important plant species in increasing the amount of urban green biomass, lifting the overall greening level and improving the ecological environment; among vines growing vertically, some of them climb up by using sucker or tendril and some hang down and cover the ground to form beautiful landscape by using their branches and leaves or flowers; creating the natural communities landscape of vines and other types of plants that are interdependent with each other to show the beauty of nature--"vines winding around trees, and trees intertwined with vines".

\section{A. Diversified Species of Vines}

The vine garden collects more than 500 vine species belonging to more than 50 families. Thereinto, there are 56 species of China endemic species and 21 Yunan endemic species; rare or endangered species: Beaumontia grandiflora, Getonia floribunda and Marsdenia incisa; minimum population plants: Chonemorpha verrucosa, Parepigynum funingense, Mucuna castanea, Gnetum montanum, Aristolochia gigantea and other vines. Of the climbing type vines in the vine garden, there are 218 species of winding vines, 46 species of tendril vines, 9 grapple vines, 9 creeping vines, 7 absorbing vines and 124 hanging vines.

\section{B. Landscape Characteristics of Specialized Garden}

The design of vine gardens draw lessons from Chinese traditional garden landscape techniques, combined with the five elements of plants, architecture, rock, water and gardens, with full use of the growth characteristics of vine. Three key areas, the entrance landscape area, comprehensive service area and central landscape area, are highlighted. Taking the advantages of growth characteristics of vines, a variety of space landscapes are formed combined with different elements, such as walls, gallery frames, roofs, wall fences, garden ornaments and ramps

1) Landscape characteristics of entrance area: The entrance of vine gardens accesses to the botanical garden's tour bus transfer station, in which the tourists are relatively concentrated. The spacious entrance space meets the needs of tourists' distribution. In the entrance area, the starting point of landscape is a large wooden-structure flower group, and the romantic atmosphere is built with Cissus sicyoides, with the integrated service building (Tengming House) as the background. The pergola groups contain two groups of L pergolas and 9 single pergolas, and two L-shaped pergolas and a quadrangle built around Tengming House. In the courtyard, 9 cubic-shaped independent pergolas are designed to form an enclosure space.

In the Tengming House, the left L-shaped pergola is cultivated with Pyrostegia venusta, with orange inflorescences hung all over the pergola, which is really bustling. And the left L-shaped pergola is cultivated with Cissus sicyoides that is a characteristic plant of the tropics. Cissus sicyoides is moistureloving, and the small pool beside the pergola increases the air humidity, which satisfies the physiological needs of Cissus sicyoides. Its aerial root like a curtain is spectacular, creating a romantic atmosphere in the entrance area.

The nine pergolas choose plants with bright colors, long flowering period and soft and drooping branches. At the same time, they pay more attention to the different flowering period to ensure the flowers bloom all the year round, and there are flowers in all the year round. For example, there are Antigonon leptopus, Clerodendrum X speciosum, Pandorea jasminoides, Clitoria ternatea and Passiflora coccinea.

2) Landscape characteristics of comprehensive service area: The west scenic area of the tropical botanical garden covers an area of $3000 \mathrm{mu}$, but there are only four tourist 
comprehensive service points, such as exotic flower garden, hotel area, shade garden and Museum. The former staff canteen in the vine garden provides a good complement to the comprehensive services of west scenic area. This is the transitional part of the vine garden and Bamboo Garden. It is also a place where visitors need to have a rest after visiting most scenic area.

The purpose of transforming the staff canteen into a service center is to provide flexible space for buildings to meet different needs. Drawing on the sloping roof of Dai residence and the form of two-floor terrace, the existing coconut trees and buildings are integrated into one, which increased the use space of buildings and reflects the relationship between Dai People's living and ethnic food plants. The two-floor veranda located on the southeast side of platform, aims to enrich the architectural image and provide a higher view to enjoy the scenery.

In terms of environmental design, we refer to the idea that Dai villages live near the mountain areas and village villages are covered in the green bamboo forests. The pool, the pergola and the building are combined, and the outdoor scope of service center is limited, with more landscape and enjoyment. The plant is mainly arranged with bamboo and vines. On the one hand, it hints at the neighboring vine garden and bamboo garden; on the other hand, it deduces the poetic meaning of $\mathrm{Li}$ Bai's "green bamboo accesses to the secluded path, and the sunglo brushes the clothes line".

We shall make full use of the roof of the existing building, and use Clerodendrum $X$ speciosum, Celastrus angulatus, Plukenetia volubilisLinneo Pentalinon luteum to form an ecological roof with thick green leaves and a swaying posture. And it can effectively soften the hard edges of the building, manifests the ecological landscape design of botanical garden, and it is another display form for the tropical vine.

3) Landscape characteristics of central landscape area: The landscape area of Vine Garden Center is a landscape sequence composed of garden ornamental vine, which is not only a business card showed to the public, but also a core area for sightseeing and a region of national culture.

With three arches (Jingmen) as the main axis, combined with corridors, pergolas, walls, windows and other garden buildings, we use the faldstools, lighting, plant interpretation cards, flowerpots, bottle ornaments, fence and other garden architecture pieces with tropical good vines to form garden ornamental vine areas. As Dai village is built near the mountains and the waters, there are 3 water scenic spots in the central landscape area, representing the theme style from the gardening display to the natural return -- from the city to the countryside. And it also shows Dai people prefer living near the waters, and at the same time increases the humidity of the environment to create a small environment for the growth of vine plants in "Fig. 1".

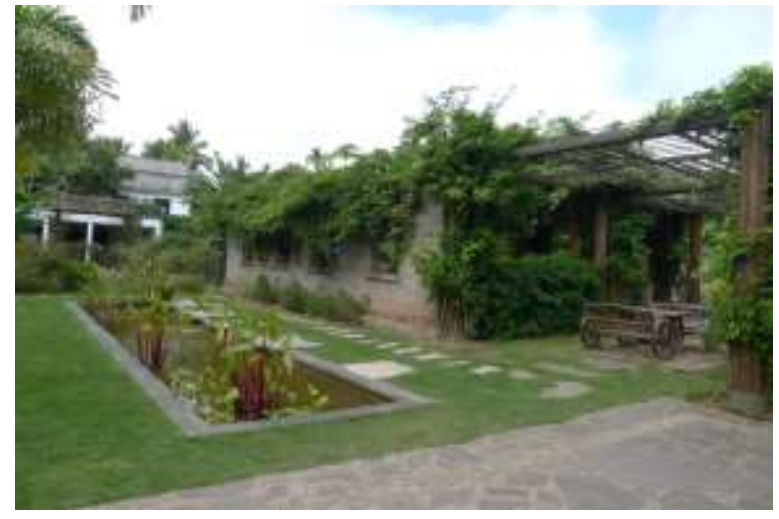

Fig. 1. Waterscape.

The preserved old buildings and walls are traces of history, the life mark of several generations of scientific workers in botanical gardens, and an important area for the historical and cultural heritage of botanical gardens. These old facilities, together with the newly built fence and pergolas, are used as the climbing carriers for vine plants, forming the space screen of cane winding fence, absorbing walls and leaping pergolas. And it shows the characteristics of vine trees and the richness of vine, and shows the delicate and rough beauty of vine.

Each Dai village has a central square, the households to household are separated by bamboo and built into courtyards. There are planted with Cocos nucifera, Musa nana, Mangifera indica, Artocarpus heterophyllus, Spondias pinnata and Areca catechu around the villages. On the central landscape area's city square, city pergolas and courtyards, the pergolas, galleries and archways are used as the pillars. Some vines with unique shapes, bright colors and elegant posture are selected. For example, there are 120 species of vines such as Bauhinia SPP, Passiflora SPP, Aristolochia SPP.

According to different landscape sketches, some potted, weaving and covering methods are chosen to be combined with all kinds of garden sketches. For example, three archways were planted respectively with Passiflora coccinea, Congea tomentos and Sabia parviflora. The porch pavilion is planted with Bauhinia spp and Passiflora spp; the lampposts are twined with Syngonium podophyllum; the simple scene wall is attached with Ficus pumila; Planting Pratia nummularia is planted in the flowerpot; all these form a unique green landscape in Xishuangbanna.

The old walls are rough and more enclosed with barrier fence and barrier space in "Fig. 2". According to different materials in plant selection, different vines are selected. Thunbergia coccinea, Quamoclit pennata and Psophocarpus tetragonolobus (Psophocarpus tetragonolobus) formed a strong contrast with the brick walls; Clerodendrum X speciosum with luxuriant branches and flowers, Clitoria ternatea and Urceola rosea are used to divide space and block the line of sight. For protection and isolation, we choose vines with branchlets, such as Rosa multiflora, Ye Bougainvillea spectabilis and Mansoa Alliacea. 


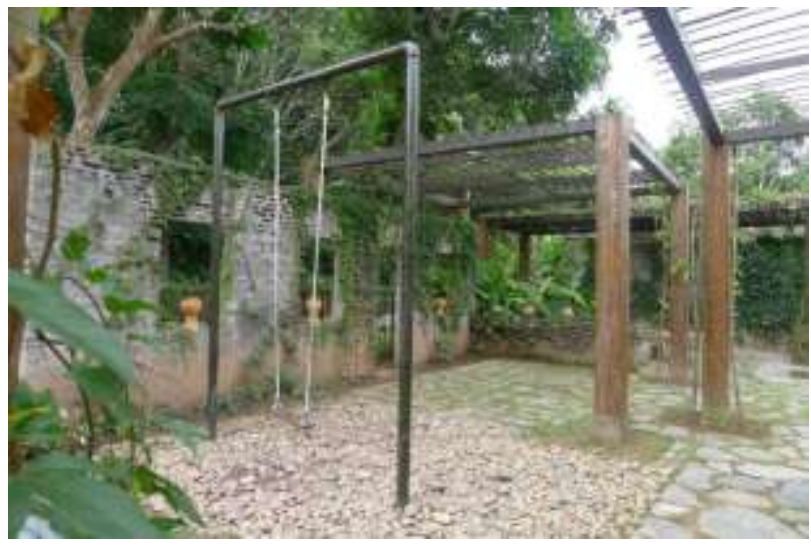

Fig. 2. Combination of wall, porch and vine.

The rural courtyard area appropriately incorporated the elements of Banna Dai nationality into it. About 50 species of vines such as Cucurbitaceae, Menispermaceae, dioscorea (Dioscoreaceae), Hernandiaceae, and Malpighiaceae were collected. The Dai household appliances (hoe, pedals, bamboo cages), bamboo woven fences, local pottery, bowl, charcoal wood and broom are decorated with plants that do not need meticulous management. The plants include edible wild vine vegetables (bitter vine, safflower, skateboard, etc.) and local vine wild flowers.

Using gallery frames to display vine is the most widely used method of vine utilization. Most of the vines in the garden are mainly made of wood structure, and their colors are natural to highlight the natural breath. And there are also masonry structures, iron structures and mixed structures. According to the characteristics of plant texture and plant size, we display the Pyrostegia venusta, Millettia spp., Passiflora spp., Momordica cochinchinensis, Bauhinia championii, and Antigonon leptopus, Mucuna spp., Bauhinia spp., Entada phaseoloides, Quisqualis indica "Double Flowered", Strongylodon macrobotrys and Afgekia filipes.

\section{CONCLUSION}

At present, XTBG vine garden is the garden with the largest area of land, the richest vines and the most varieties, and is also the largest germplasm gene pool in protection and preservation of vine in vivo. It has high academic value and scientific research significance, and has realized the basic functions of "species preservation, landscape display and science popularization education". With its strong regional cultural elements, the vine garden has good ornamental and recreational functions, providing one of the distinctive tourist destinations for Chinese and foreign tourists. It is one of the vine specialized gardens with regional and cultural characteristics both at home and abroad. The special garden is in line with the design theme of "Science botanical garden with high species enrichment and strong national culture" in the botanical garden construction, adhering to the core concept of botanical tradition, "constant knowledge and differences", and the botanical garden spirit of "Accountability, reality, and harmony". It embodies the strategic thinking of "protection and utilization of global biodiversity" and accords with the environmental protection thought that is consistent with the global vision of a community of shared future for mankind. It also provides regional scientific research platform and experimental base for "Relocation protection and resource plant database construction of rare and endangered plants in China". Vine garden shows the unique vines in Xishuangbanna, and the landscape design fully reflects the use of existing environment and continuity of site culture. And it embodies many kinds of landscape uses of vine plants, which is an important display window for landscape seedling development and landscape design.

\section{REFERENCES}

[1] Liu Min, Ornamental Botany [M]. Beijing: China Agricultural University Press, 2016.8. 刘敏. 观赏植物学 $[\mathrm{M}]$. 北京:中国农业大学 出版社,2016.8.

[2] Xiong Jihua, Tang Dai, Vines Flower [M]. Beijing: China Agricultura University Press, 2000. 熊济华,唐岱.藤茵花卉[M].北京:中国林业出 版社, 2000 .

[3] Zhou Yuanrui. Ecological Characteristics of South China Vines[J]. Journal of Plant Ecology and Geobotany, 1984,8(3):199-206. 周远瑞. 华南藤本植物的生态学特性 $[\mathrm{J}]$. 植物生态学与地植物学 丛刊, 1984, 8(3): 199-206.

[4] Chen Jinyong. Application of Wall Garden and Wall Garden Plants in Urban Gardens [J].Chinese Garden, 2008,06,69 72. 陈进勇.墙园及墙 园植物在城市园林中的应用 [J].中国园林,2008,06,69 72.

[5] You Tian. Research on Landscape Design of Vine Specialized GardenTake the Special Vine Garden of Hunan Forest Botanical Garden as an Example [D]. Hunan: Hunan Agricultural University, 2013. 游甜.藤本 植物专类园景观设计研究-以湖南省森林植物园藤本植物专类园为 例[D].湖南:湖南农业大学,2013.

[6] Sun Liandi, Chen Yi. Manqu Garden [J]. Gardens, 2012,(9),40-41. 孙连 棣,陈奕. 蔓趣公园 $[J]$. 园林,2012,(9),40-41. 